\title{
Identification of responsive genes and analysis of genes with bacterial- inducible cis-regulatory elements in the promoter regions in Oryza sativa L.
}

\author{
Abbas SAIDI ${ }^{1,2}$, Zohreh HAJIBARAT ${ }^{1}$, Zahra HAJIBARAT ${ }^{1}$
}

Received January 28, 2019; accepted July 06, 2020.

Delo je prispelo 28. januarja 2019, sprejeto 06. julija 2020.

Identification of responsive genes and analysis of genes with bacterial-inducible cis-regulatory elements in the promoter regions in Oryza sativa L.

Abstract: Bacterial blight of rice caused by Xanthomonas oryzae pv. oryzae (Xoo) is one of the most critical diseases in rice. In order to study rice responsive genes to bacterial stress, microarray data were retrieved from GEO dataset. To identify the responsive genes to biotic stress (bacteria) bioinformatic tools were employed and the data presented in the forms of heatmap, gene ontology, gene network, and cis-element prediction were used. Almost all responsive genes were downregulated at around $3 \mathrm{~h}$ time point and up-regulated $24 \mathrm{~h}$ time point in response to bacterial stress in rice varieties (Oryza sativa subs. japonica 'IR64', 'IRBB5', 'IRBB7' and 'Y73'). Gene ontology showed that genes are involved in different biological processes including translation and cellular protein metabolic processes. Network analysis showed that genes expressed in response to pathogen infection (Xoo) included protein translation, eukaryotic initiation factors (eIFs), ribosomal proteins, protein ubiquitin, and MAPK genes. The genes expressed in response to bacterial stress can enable plant balance between synthesis and degradation of proteins which in turn allows plants for further growth and development. TATA-box and CAAT box had the highest number of cis elements involved in bacterial stress. These genes can provide novel insights into regulatory mechanisms in biotic stress responses in rice. Identification of bacterial stress response/tolerance genes of rice can assist the molecular breeding of new rice varieties tolerant to bacterial stress.

Key words: rice; differentially-expressed genes (DEGs); bacterial stress; gene ontology; gene network
Določanje odzivnih genov in analiza genov, ki jih $\mathrm{v}$ promotorskih območjih riža (Oryza sativa L.) inducirajo bakterijski cis-regulatorni elementi

Izvleček: Bakterijski ožig riža, ki ga povzroča vrsta Xanthomonas oryzae pv. oryzae (Xoo) je ena izmed najbolj kritičnih bolezni riža. Za preučevanje odzivnih genov pri rižu na bakterijski stres so bili pridobljeni podatkovni seti eksperimenta mikromrež iz podatkovne baze GEO. Za določanje odzivnih genov na bakterijski stres so bila uporabljena bioinformacijska orodja, katerih rezultati so bili predstavljeni v obliki barvnih vizualizacij, genske ontologije, genskega omrežja in napovedi cis-elementov. Skoraj pri večini odzivnih genov je bilo izražanje zavrto po približno 3 urah in aktivirano po približno 24 urah kot odziv na bakterijski stress pri sortah riža kot so Oryza sativa subspecies japonica 'IR64', 'IRBB5', 'IRBB7' in 'Y73'. Genska ontologija je pokazala, da so ti geni vključeni v različne biološke procese, vključno s translacijo in presnovnimi procesi proteinov v celici. Analiza genskega omrežja je pokazala, da so geni, ki so se izrazili kot odziv na okužbo s patogenom (Xoo) vključevali translacijo proteinov, eukariontske iniciacijske faktorje (eIFs), ribosomalne proteine, protein ubikvitinin in MAPK gene. Geni, ki se izrazijo kot odziv na bakterijski stres omogočajo rastlini usklajevanje med sitezo in razgradnjo beljakovin, kar ji omogoča nadaljno rast in razvoj. Zaporedja nukleotidov kot so TATA in CAAT območja so imela največje število cis elementov povezanih $\mathrm{z}$ bakterijskim stresom. Ti geni lahko dajo nove vpoglede $\mathrm{v}$ regulatorne mehanizme pri odzivu riža na biotski stres. Identifikacija na bakterijski stres tolerantnih in odzivnih genov lahko pripomore pri molekularnem žlatnjenju novih sort riža, tolerantnih na bakterijski stres.

Ključne besede: riž; diferencialno izražanje genov (DEGs); bakterijski stres; genska ontologija; genske mreže

1 Shahid Beheshti University, Faculty of Life Sciences and Biotechnology, Department of Plant Sciences and Biotechnology, Tehran, Iran

2 Corresponding author, e-mail: abbas.saidi@gmail.com 


\section{INTRODUCTION}

Rice (Oryza sativa L.), the world's most important staple crop, is the primary source of food for more than three billion people (Dawe, 2000). Rice production is affected by both biotic and abiotic stresses (Sharma et al., 2012). Bacterial blight is one of the most destructive diseases of rice causing serious yield loss to rice varieties (Sharma et al., 2012; Agrawal et al., 2002). Rice has been used as a model crop in host-pathogen interactions, bacterial pathogenesis and defense responses in monocotyledonous plants (Li et al., 2006). Recently, high-throughput techniques have provided appropriate opportunities for detecting complex signaling pathways and genetic networks involved in response to biotic and abiotic stresses (Meena et al., 2017). One of the most important techniques is microarray analysis that can be employed for such analysis. Microarray analysis showed that hundreds of genes involved in MAP cascade, hormone signaling, cell wall, and primary and secondary metabolism were induced or inhibited after Xoo infection (Grewal et al., 2012). According to other studies, genes induced and expressed in response to abiotic and biotic stresses include eukaryote initiation factors (eIF3), the DEAD-box (eIF4), ribosomal proteins (RPL and RPS), MAPK kinases, peptidases, and ubiquitin genes. Ribosomal protein (RP) is a critical factor in joining the $40 \mathrm{~S}$ and $60 \mathrm{~S}$ ribosomal subunits into a functional $80 \mathrm{~S}$ ribosome (Eisinger et al., 1997). RPs have essential roles in stabilizing the ribosomal complex and mediating polypeptide synthesis in addition to extra-ribosomal functions such as their involvement in response to the environmental stresses (Sormani et al., 2011). Plants can balance between protein synthesis and degradation which in turn will allow them to grow further and develop.

In the present study, an effort has been made to dissect the rice-bacterial interaction system at 3,6,12, and 24 hours after inoculation (hai) in IR24, IRBB5, IRBB7, Y73 hosts based on publicly available data sets (Chen et al., 2016). Infection with Xanthomonas oryzae pv. oryzae, leads to up-regulation of a large number of RPS genes by BLB. It has been reported that RP genes were significantly up-regulated in response to abiotic and biotic stresses in rice (Moin et al., 2016; Sormani et al., 2011). For resistance, controlling the turnover of a protein is a fundamental regulatory mechanism in post-translational modifications in plants, allowing rapid response and improved plant adaptation to internal and external signaling produced by changing environmental conditions (Boycheva et al., 2015). The aims of this work included identification of genes responsive to bacterial stress, genes associated with translation, ribosomal proteins, protein biosynthesis, and signaling pathways. Further, cis-regulatory elements in the promoter regions of the up-regulated genes were predicted.

\section{MATERIALS AND METHODS}

Pathogen resistance microarray data were downloaded from NCBI GEO database (www.ncbi.nlm.nih. gov/geo/) in response to bacterial pathogen Xanthomonas oryzae pv. oryzae in Oryza sativa (subspecies japonica 'IR64', 'IRBB5', 'IRBB7') represented by GSE33411 data set and ('Y73') variety represented by GSE36093 dataset (Chen et al., 2016). These datasets consist of transcriptome data with three biological replicates (a total of 51 samples). To study the regulation of genes at time points, the genes were analyzed from a range of $3 \mathrm{~h}$ to $24 \mathrm{~h}$ in response to bacterial infection.

Analysis of data was carried out by fold change which was based on $\log 2$ ratio, followed by normalizing the data using Robust Multiarray Average (RMA) method (Bolstad et al., 2003) and applied to Affymetrix data using $\mathrm{R}$ software with the affy package. Then the ratio expression of the genes examined under $3 \mathrm{~h}$ to $24 \mathrm{~h}$ in response to bacterial infections were compared to control and the DEGs were selected by $p-<0.05$ as the statistical significance. The filtered data with DEGs $>2$ was considered as up-regulated genes and DEGs $<-2$ was considered as down regulated. The probe IDs were converted into Affymetrix IDs to gene names and to detect the function of genes affected by oryzaexpress database (http://bioinf. mind.meiji.ac.jp/OryzaExpress/ID_converter). Probe sets were mapped to the MSU Rice Genome Annotation Project gene set (release 6.1). In this study, analysis of data was performed by fold change which was based on $\log 2$ ratio, followed by normalizing the data (the ratio expression of the genes examined under bacterial infection to control). BAR database (http://bar.utoronto.ca/ welcome.htm) was used to identify co-expressed genes and to draw the protein-protein interaction networks (Szklarczyk et al., 2016). Single probes were matched with only one ID gene. In the datasets, samples and genes were filtered to reduce missing data between $-2<$ to $<2$ fold changes. Gene ontology analysis was carried out using the Singular Enrichment Analysis (SEA) tool offered by agriGO (Du et al., 2010).

\subsection{THE NETWORK OF CO-EXPRESSED GENES}

The Pearson correlation coefficient of bacterial rice genes were obtained from the BAR database. The interactions among all genes were performed using the "The Rice Interactions Viewer" web in BAR (http://bar.uto- 
ronto.ca/welcome.htm) (Hossain et al., 2016). Nodes are colored according to its subcellular localization, edges are colored according to its co-expression correlation, and the line thickness correlates to CV. Queries produced a database of 37472 predicted and 430 confirmed Rice interacting proteins (http://bar.utoronto.ca/welcome.htm).

\subsection{EXPRESSION STUDY OF BACTERIAL GENES}

In order to figure out the differential gene expression (DEGs) under developmental stage, bacterial gene expression data was extracted by genevestigator from $O$. sativa database using Affymatrix Rice Genome Array platform (OS_AFFY_RICE-0) and 'Perturbations' tool. DEGs with $p<0.05$ and $\log$ fold-change values $\geq 2$ and $\leq-2$ were selected for genes. Genevestigator (https:// genevestigator.com/gv/) was utilized to determine the expression of bacterial genes in different developmental stages in rice.

\subsection{PREDICTION OF CIS REGULATORY ELE- MENTS}

To access the presence of bacterial stress-responsive cis-regulatory elements, the nucleotide sequences of_1 $\mathrm{kb}$ upstream of each gene was retrieved from the database and submitted to the Plant Cis-Acting Regulatory Elements database (PlantCARE) (http://bioinformatics. psb. ugent.be/webtools/ plantcare/html/) (Lescot et al., 2002). PlantCARE program is designed to identify new regulatory elements under in silico from transcriptome data. The database can be queried on names of transcription factor (TF) sites, motif sequence, function, species, cell type, gene, TF and literature references.

\section{RESULTS AND DISCUSSION}

In this study, we surveyed responsive genes to bacterial stress using different bioinformatics databases. Here, we have described names and alternate names of genes, upstream promoter of significant genes, gene ontology, and expression of their genes (Table 2). Genes were down-regulated at around $3 \mathrm{~h}$ time point and were up-regulated at $24 \mathrm{~h}$ time point in response to bacterial stress in all rice cultivars (IRRB5, IRRB7, IR64, and Y73). The down-regulated genes at around $3 \mathrm{~h}$ time point can be assumed to have a pivotal role in early defense signaling and might have a function in reconstructing the proteins synthesis apparatus (Ouyang et al., 2007). Thus, the genes up-regulated after 24 hours of stress may interfere with the synthesis and degradation of proteins.

\subsection{DETECTION OF RESPONSIVE-GENES IN- VOLVED IN CO-EXPRESSED GENE NET- WORK}

The network analysis of significant genes (in total 251 ) is given in Figure 3. Nodes are illustrated according to protein subcellular localization, edges are illustrated according to its co-expression correlation and the line thickness correlates to $\mathrm{CV}$. Alternatively, based on rice gene expression data sets available in the BAR database, nodes can be colored according to their expression levels in specific organelles (Toufighi et al., 2005). For each edge connecting a pair of proteins, the RIV is able to show different colors based on the co-expression value (PCC). Overall, for a pair of proteins to physically interact, each protein must be located at the same or adjacent subcellular compartments either permanently or transiently.

In the network, LOC_Os01g66520 seemed to be the central protein encoding the "Serine/Threonine Protein Kinase" (STK). Most of the proteins in this network seem to be localized mainly in nucleus (blue), cytoplasm (pink), chloroplast (green), and mitochondria (light blue). These proteins encode mainly for the significant genes such as LOC_Os04g30780 (eIF-3h), LOC_Os09g36300 (OsLon4), LOC_Os05g01450 (eIF3f), LOC_Os02g55370 (RPL39), and LOC_Os03g08010 (EF-TU) (Figure 1). Genes involved in the network analysis such as Serine/Threonine Protein Kinase (STK) pathways and translation protein genes (eIFs, ribosomal protein, EF-Tu) have been found to play important roles in response to Xanthomonas oryzae (Grewal et al., 2012). Serine/Threonine Protein Kinase (STK) is involved in the disease resistance signaling process (Ülker \& Somssich 2004). Accroding to other studies, the transcriptional activity of MPKs has been observed in response to several biotic stresses (Agrawal et al., 2002Complexity of the genetic networks involved in defense response has also been reported in MPKs. Based on previous results, several stress-responsive genes (MPKs) are regulated by biotic and abiotic stresses (Ghanashyam \& Jain, 2009; Jain \& Khurana, 2009).

Proteins expressed in the nucleus include LOC Os01g03070 (eIF-3a (transposon), LOC_Os05g01450 (eIF3-F), and LOC_Os03g59310 (ribosomal protein). Analysis of genes network showed up-regulation of ribosomal proteins, eIFs genes, and MAPK genes. Kolupaeva and colleagues suggested that eIF3 plays an important role in separating the subunits in the terminal 
Table 1: Characteristics of responsive genes to bacterial stress

\begin{tabular}{|c|c|c|c|c|}
\hline No & Affymetrix probe ID & MSU7 & RAP-ID & Function \\
\hline 1 & Os.10120.1.S1_at & LOC_Os06g36160 & Os06g0555400 & 40 S ribosomal protein S19-like \\
\hline 2 & Os.10132.1.S1_at & LOC_Os09g36300 & Os09g0533400 & OsLon4 (Putative Lon protease homologue) \\
\hline 3 & Os.10955.1.S1_at & LOC_Os02g54700 & Os02g0788400 & eIF-3g \\
\hline 4 & Os.11049.1.S1_at & LOC_Os03g59310 & Os03g0807800 & Ribosomal protein \\
\hline 5 & Os.11168.1.S1_x_at & LOC_Os02g55370 & Os02g0796900 & 60S ribosomal protein L39 (RPL39) \\
\hline 6 & Os.11420.1.S1_at & LOC_Os05g01450 & Os05g0104800 & eIF-3f \\
\hline 7 & Os.12189.2.S1_x_at & LOC_Os11g38959 & Os11g0602600 & $40 \mathrm{~S}$ ribosomal protein $\mathrm{S} 9$ \\
\hline 8 & Os.12413.1.S1_at & LOC_Os03g22340 & Os03g0343500 & 60 S ribosomal protein L22-2 (RPL22-2) \\
\hline 9 & Os.12625.1.S1_a_at & LOC_Os03g08010 & Os03g0177400 & Elongation factor $\mathrm{Tu}(\mathrm{EF}-\mathrm{Tu})$ \\
\hline 10 & Os.12772.1.S1_at & LOC_Os03g13170 & Os03g0234200 & Ubiquitin fusion protein \\
\hline 11 & Os.139.1.S1_at & LOC_Os06g48750 & Os06g0701100 & eIF-4a (DEAD-box ATP-dependent RNA helicase) \\
\hline 12 & Os.14437.1.S1_at & LOC_Os01g66520 & Os01g0888700 & Serine/threonine-protein kinase (STK) \\
\hline 13 & Os.14589.1.S1_at & LOC_Os03g56241 & Os03g0773150 & 40S ribosomal protein S29 \\
\hline 14 & Os.28076.1.S2_at & LOC_Os01g03070 & Os01g0120800 & eIF-3a (transposon) \\
\hline 15 & Os.38164.1.S1_at & LOC_Os12g38180 & Os12g0569700 & OsHsp23.7 \\
\hline 16 & Os.40424.1.S1_at & LOC_Os01g54340 & Os01g0747300 & Plant-specific domain TIGR01615 family protein \\
\hline 17 & Os.41468.1.S1_at & LOC_Os01g47050 & Os01g0659900 & OsFbox033 \\
\hline 18 & Os.4714.1.S1_at & LOC_Os07g01870 & Os07g0109500 & Ribosomal protein L13 family protein (RPL13) \\
\hline 19 & Os.47337.1.S1_at & LOC_Os02g10820 & Os02g0202600 & Sel1 repeat domain containing protein \\
\hline 20 & Os.5326.1.S1_a_at & LOC_Os05g02880 & Os05g0120100 & Splicing factor \\
\hline 21 & Os.7573.1.S1_at & LOC_Os06g49140 & Os06g0704900 & Ribosomal RNA large subunit methyltransferase J \\
\hline 22 & Os.8580.1.S1_at & LOC_Os04g30780 & Os04g0376500 & eIF-3h (Eukaryotic translation initiation factor 3 subunit $\mathrm{H}$ ) \\
\hline 23 & OsAffx.4176.1.S1_at & LOC_Os04g54640 & Os04g0639300 & Peptidase \\
\hline
\end{tabular}

codon (Kolupaeva et al., 2005). Further, eIF3 gene has been shown to improve stress tolerance and thus can be utilized through transgenic approaches. Similar studies confirming our results suggest that large and small subunits of ribosomal protein provide a better understanding of stress response in rice (Hummel et al., 2012; Saidi \& Hajibarat, 2019).

Cytosolic localized proteins are estimated to interact with nuclear and mitochondrial localized proteins, providing possible import/ export regulation proteins such as transcription factors (Ho et al., 2012). In addition, several proteins are also expressed in the vacuole including LOC_Os03g05980 (protein 40S ribosomal protein S9-2) and LOC_Os01g03070 (protein translation initiation factor SUI1, putative, expressed).

Analysis of network showed that only a few proteins are located in each of the chloroplast, nucleus, cytoplasm and vacuole. LOC_Os07g01870 (RPL13) and LOC_Os07g02340 (RPL22-2) are mainly translational proteins localized in the chloroplast (Figure 1). For resistance to the bacterial stress, large and small subunits of ribosomal genes (RPS and RPL), associated with pro- teins translation, are regulated. Other genes associated with translation of proteins include up-regulation of initiation and elongation factors. In addition, peptidase, ubiquitin, and OsLonP4 protease genes are expressed in response to bacterial stress. Further, serine / threonine kinase genes are also expressed in response to bacterial stress.

\subsection{DIFFERENTIALLY-EXPRESSED GENES IN RESPONSE TO DEVELOPMENTAL STAGES}

Microarray data indicated an up regulation of significant genes during different developmental stages; this may be due to the presence of different cis elements (Figure 4). As a result, these genes can play key roles in different growth and developmental stages under abiotic and biotic stresses. RPS and RPL genes were also up-regulated during different developmental stages indicating that both can play important roles in multiple biological processes, protein synthesis, cell growth, development, and apoptosis (Warner \& McIntosh, 2009). Ribosomal 


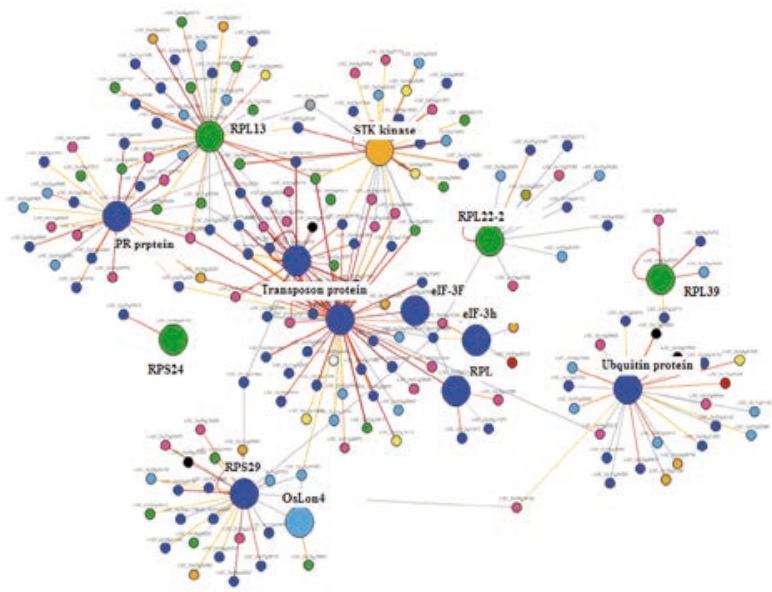

Figure 1: Predicted gene network for responsive genes to bacterial stress, drawn up by the BAR database where the drawn lines represent the relationships among genes.

proteins (RPs) are vital in ribosome biogenesis and protein synthesis and play a key role in diverse developmental processes (Saha et al., 2017).

\subsection{ANALYSIS OF RPL AND RPS IN RESPONSE TO BACTERIAL STRESSES}

RPs have long been known primarily for their housekeeping functions. RPL13, RPS7, and RPS9-2 responded to bacterial stresses and biotic stress. However, there are several reports showing RPs having several functions under different stress conditions (Warner \&McIntosh, 2009). Out of the 80 RPs encoded by 3200 genes in Arabidopsis, 32 are small subunits and 48 are large subunits (Wang et al., 2013). In rice, there are 34 large protein subunits with multiple gene copies encoding ribosomal proteins (McIntosh \& Bonham-Smith, 2006: Moin et al.2016).

Although many of the RPS and RPL genes are expressed in response to bacterial stress, however, they cannot be considered as house-keeping as their level of expression changes in response to environmental signals (Moin et al., 2016). Based on microarray data, we have suggested that RPL and RPS genes might be useful as candidate genes for manipulating stress tolerant rice varieties.

Very few studies have been conducted on RPL and RPS genes of rice (Moin et al., 2016; Wang et al.2003). We performed an extensive analysis on the expression of all ribosomal genes (RPS) induced in rice. Differential expression of RPS and RPL genes under bacterial stress condition significantly increased expression. RPL and RPS genes can be induced under different stresses such as heat, cold, low irrigation, and pathogens (Wang et al.,
2003). Each stress activates a series of cascade signaling pathways for plant survival and plant growth. Up-regulation of ribosomal genes and the presence of several regulatory elements in the upstream regions of the genes promoter (Table 1) confirm other findings that these genes may play an important role in reducing the biotic and abiotic stresses in rice (Fujimoto et al., 2000).

It has been reported that over-expression of RPL13 enhances resistance against a fungal pathogen (Verticillium dahliae Kleb.) in transgenic potato as well as upregulation of genes coding for defense and antioxidant enzymes (Yang et al., 2015; Song et al., 2020). In addition, RPS7 and RPS9-2 genes were up-regulated in response to bacterial stress. Our findings are in agreement with others who have reported that these genes are also up-regulated in response to PEG and salt treatment (Kawasaki et al., 2001). Based on our findings it can be suggested that $e I F s, R P L$, and RPS genes can be particularly promising in bringing about the tolerance to multiple stresses in rice.

Recent studies in different plant species have shown that the lack of eIF4A (DEAD-box) gene leads to decreased root formation, delayed flowering, and abnormal ovule formation suggesting that eIF4A plays an essential role in growth and development of plants (Peng et al., 2008; Maršálová et al., 2016). The Arabidopsis genome encodes eIF4A, required for the coordination between cell cycle progression and cell size (Bush et al., 2015; Saidi \& Hajibarat, 2020).

\subsection{FUNCTIONAL CLASSIFICATION OF OVER- LAPPING GENES}

Based on gene ontology (GO) classification, genes 


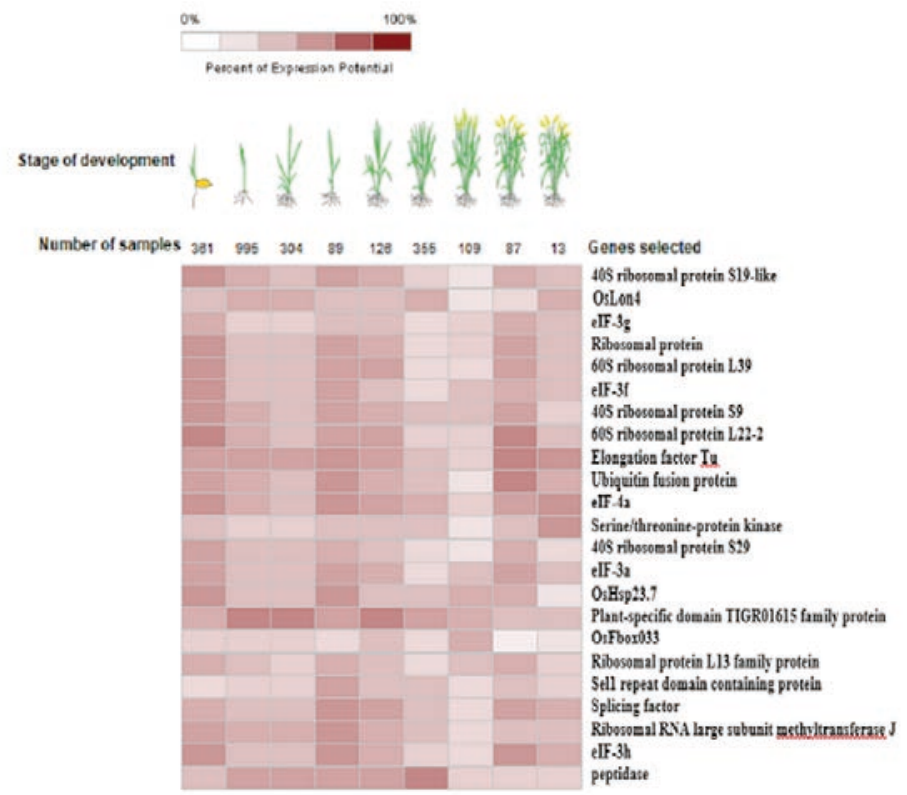

Figure 2: Heatmap representation of expression analysis of bacterial responsive genes at different developmental stages of $O$. sativa..

Table 2: Analysis of gene ontology and KEGG pathway in response to bacterial stress in rice

\begin{tabular}{llllc}
\hline & pathway ID & pathway description & count in gene set & false discovery rate \\
\hline & GO:0006412 & Translation & 4 & 0.000113 \\
Biological Process (GO) & GO:0044267 & cellular protein metabolic process & 5 & 0.00139 \\
& GO:0010467 & gene expression & 5 & 0.0029 \\
Molecular Function & GO:0003735 & structural constituent of ribosome & 3 & 0.00361 \\
Cellular Component & GO:0005840 & Ribosome & 3 & 0.00195 \\
KEGG Pathways & 03010 & Ribosome & 8 & $1.88 \mathrm{e}-11$ \\
& 03013 & RNA transport & 5 & $3 \mathrm{e}-07$ \\
\hline
\end{tabular}

responding to different treatments were categorized into different functional groups of biological processes, cellular components and molecular functions (Table 2). In the biological process category, translation, peptide biosynthetic processes and amide biosynthetic processes were the most dominant groups. In the cellular components group, ribosome subunit was the largest group, followed by intracellular and non-membrane organelles. Structural constituent of ribosome was the largest group in the molecular function, followed by structural molecule activity. Gene ontology showed that most genes are involved in translation and protein biosyntesis. GO analysis of all genes showed that the lowest gene counts responsible for translation included four genes and the highest gene count responsible for cellular protein metabolic processes and gene expression included five genes (Table 2). According to our GO enrichment analysis, significant genes had translational function in protein bio- synthesis pathway. The balance between protein synthesis and degradation is necessary to maintain and improve homeostasis and plant survival (Boycheva et al., 2015). All responsive genes were involved in both KEGG pathways including ribosome (pathway ID: 03010) and RNA transport (pathway ID: 03013) with ribosome having the highest gene count (Table 2).

\subsection{CIS REGULATORY ELEMENTS ANALYSIS}

Cis regulatory elements prediction analysis resulted in the identification of multiple stress-responsive elements in the promoter regions of some genes such as eIF-3g, eIF-4a, RPL39, RPL13, and eIF-3h (Figure 3). In addition to abiotic stresses, cis elements also respond to phyto-hormones such as ABA (ABRE-Abscisic acid responsive element and Motif IIb), MeJa (TGACG-motif 


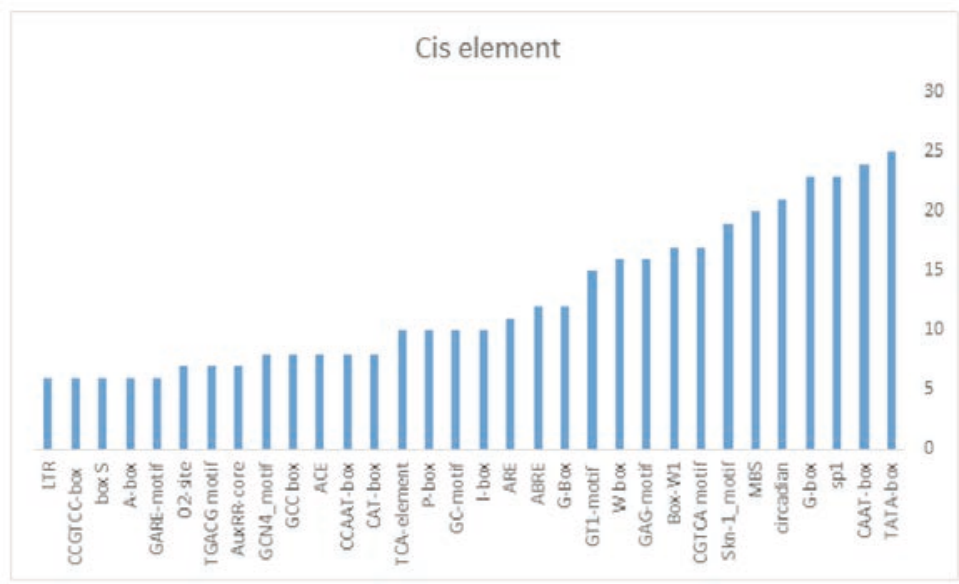

Figure 3: Cis regulatory elements detected in the region of the responsive genes and their frequency in each gene, the 1000-bp upper region of upstream of each gene were searched using the PlantCARE database (http://bioinformatics.psb. ugent.be/webtools/ plantcare/html/) to identify responsive elements to bacterial stress.

and CGTCA-motif), SA (TCA-motif), Gibberellic acid (GARE- Gibberellic acid responsive element), and Auxin (TGA-motif and AuxR-Auxin responsiveness). Only few motifs such as ABRE (abscisic acid), CGTCA and TGACG (methyl-jasmonate), GCC-box (ethylene), and TCA element (salicylic acid) were present in both A. thaliana and O. sativa PRs (Kaur et al., 2017).

Our results suggest that hormones involved in bacterial stress may play a major role in regulating stress responses. Various elicitor-responsive elements such as GCC box and W box have been observed in some genes. W-box motifs are the binding sites for stress-responsive WRKY transcriptional factors (Eulgem \& Somssich, 2007) and a Box-W1 motif, a fungal elicitor element that binds with WRKY33 transcriptional factor in response to phyto-pathogens (Lippok et al.2007; Saidi \& Hajibarat, 2018)

A detailed analysis of both abiotic and biotic responsive elements and their repeats in the promoter regions is presented in Figure 3. Cis-regulatory elements in the promoter sequences provide a good understanding of plant responses under biotic stress conditions. Genes promoter analysis revealed that TATA-box and CAATbox were present in majority of promoter regions of the genes. GATA-box, G-box, Box-4, GAG, GA-motif and I-box are known as light responsive cis-elements (LREs) and have been found in the regulatory region of lightregulated genes, apparently essential for light-controlled transcriptional activity (Gilmartin et al., 1990). TGACG motif is methyl jasmonate responsive element present among Arabidopsis and O. sativa PR gene sequences (Kaur et al.2017). The transcription of TGACG mediated PR sequences is regulated by binding of BZIP TGA factor to TGACG element (Wang et al., 2013). According to the studies performed on the regions of gene promoter, regulatory elements of the genes responsive to auxin and jasmonate (jasmonic acid) hormones are up-regulated in response to the infection of the pathogen, perhaps due to the presence of WRKYs in the promoter regions (Dowd et al., 2004; O'Brien et al., 2013).

\section{CONCLUSION}

In the present study, a comprehensive analysis of responsive genes, in terms of co-expressed network, cis-elements, gene ontology, and expression study in promoter regions in rice was performed. Analysis of promoter regions revealed the presence of different types and frequencies of cis elements among genes. In our analysis, several cis elements including TATA, CAAT-box, Sp1, and G-box were identified in the promoter regions of the responsive genes. Among the responsive genes, RPL and RPS were the most up-regulated genes during developmental stages. In this study, the identified responsive genes to bacterial stress can be utilized as candidate genes for crop breeding. Plants activate these genes to balance between the synthesis and degradation of proteins under stress conditions. This work suggests that the cis elements in the promoter regions of the genes can provide new ways for improving plant resistance against pathogens. Also, analysis of responsive gene expression revealed that these genes can be considered for rice breeding for resistance to abiotic and biotic stresses.

\section{REFERENCES}

Agrawal, G.K., Rakwal, R. and Iwahashi, H. (2002). Isolation of 
novel rice (Oryza sativa L.) multiple stress responsive MAP kinase gene, OsMSRMK2, whose mRNA accumulates rapidly in response to environmental cues. Biochemical and Biophysical Research Communications, 294(5), 1009-1016. https://doi.org/10.1016/S0006-291X(02)00571-5

Boycheva, I., Vassileva, V., Revalska, M., Zehirov, G. and Iantcheva, A. (2015). Cyclin-like F-box protein plays a role in growth and development of the three model species Medicago truncatula, Lotus japonicus, and Arabidopsis thaliana. Research and Reports in Biology, 6, 117-130. https://doi.org/10.2147/RRB.S84753

Bolstad, B.M., Irizarry, R.A., Åstrand, M. and Speed, T.P. (2003). A comparison of normalization methods for high density oligonucleotide array data based on variance and bias. Bioinformatics, 19(2), 185-193. https://doi.org/10.1093/bioinformatics/19.2.185

Chen, X., Dong, Y., Yu, C., Fang, X., Deng, Z., Yan, C., \& Chen, J. (2016). Analysis of the proteins secreted from the Oryza meyeriana suspension-cultured cells induced by Xanthomonas oryzae pv. oryzae. PloS One, 11(5). https://doi. org/10.1371/journal.pone.0154793

Dowd, C., Wilson, I.W. and McFadden, H. (2004). Gene expression profile changes in cotton root and hypocotyl tissues in response to infection with Fusarium oxysporum f. sp. vasinfectum. Molecular Plant-Microbe Interactions, 17(6), 654667. https://doi.org/10.1094/MPMI.2004.17.6.654

Du, Z., Zhou, X., Ling, Y., Zhang, Z. and Su, Z. (2010). agriGO: a GO analysis toolkit for the agricultural community. Nucleic acids research, 38(suppl_2), W64-W70. https://doi. org/10.1093/nar/gkq310

Eisinger, D.P., Dick, F.A. and Trumpower, B.L. (1997). Qsrlp, a $60 \mathrm{~S}$ ribosomal subunit protein, is required for joining of $40 \mathrm{~S}$ and 60S subunits. Molecular and Cellular Biology, 17(9), 5136-5145. https://doi.org/10.1128/MCB.17.9.5136

Eulgem, T. and Somssich, I.E. (2007). Networks of WRKY transcription factors in defense signaling. Current Opinion in Plant Biology, 10(4), 366-371. https://doi.org/10.1016/j. pbi.2007.04.020

Fujimoto, S.Y., Ohta, M., Usui, A., Shinshi, H. and Ohme-Takagi, M. (2000). Arabidopsis ethylene-responsive element binding factors act as transcriptional activators or repressors of GCC box-mediated gene expression. The Plant Cell, 12(3), 393-404. https://doi.org/10.1105/tpc.12.3.393

Ghanashyam, C. and Jain, M. (2009). Role of auxin-responsive genes in biotic stress responses. Plant Signaling \& Behavior, 4(9), 846-848. https://doi.org/10.4161/psb.4.9.9376

Gilmartin, P.M., Sarokin, L., Memelink, J. and Chua, N.H. (1990). Molecular light switches for plant genes. The Plant Cell, 2(5), 369. https://doi.org/10.2307/3869087

Grewal, R.K., Gupta, S. and Das, S. (2012). Xanthomonas ory$z a e$ pv oryzae triggers immediate transcriptomic modulations in rice. BMC Genomics, 13(1), 49. https://doi. org/10.1186/1471-2164-13-49

Hummel, M., Cordewener, J.H., de Groot, J.C., Smeekens, S., America, A.H. and Hanson, J. (2012). Dynamic protein composition of Arabidopsis thaliana cytosolic ribosomes in response to sucrose feeding as revealed by label free MS E proteomics. Proteomics, 12(7), 1024-1038. https://doi. org/10.1002/pmic.201100413
Jain, M. and Khurana, J.P. (2009). Transcript profiling reveals diverse roles of auxin-responsive genes during reproductive development and abiotic stress in rice. The FEBS Journal, 276(11), 3148-3162. https://doi.org/10.1111/j.17424658.2009.07033.x

Kaur, A., Pati, P.K., Pati, A.M. and Nagpal, A.K. (2017). In-silico analysis of cis-acting regulatory elements of pathogenesisrelated proteins of Arabidopsis thaliana and Oryza sativa. PloS One, 12(9), e0184523. https://doi.org/10.1371/journal. pone. 0184523

Kawasaki, S., Borchert, C., Deyholos, M., Wang, H., Brazille, S., Kawai, K., Galbraith, D. and Bohnert, H.J. (2001). Gene expression profiles during the initial phase of salt stress in rice. The Plant Cell, 13(4), 889-905. https://doi.org/10.1105/ tpc.13.4.889

Kolupaeva, V.G., Unbehaun, A., Lomakin, I.B., Hellen, C.U. and Pestova, T.V. (2005). Binding of eukaryotic initiation factor 3 to ribosomal $40 \mathrm{~S}$ subunits and its role in ribosomal dissociation and anti-association. Rna, 11(4), 470-486. https:// doi.org/10.1261/rna.7215305

Lescot, M., Déhais, P., Thijs, G., Marchal, K., Moreau, Y., Van de Peer, Y., ... \& Rombauts, S. (2002). PlantCARE, a database of plant cis-acting regulatory elements and a portal to tools for in silico analysis of promoter sequences. Nucleic Acids Research, 30(1), 325-327. https://doi.org/10.1093/ nar/30.1.325

Li, Q., Chen, F., Sun, L., Zhang, Z., Yang, Y. and He, Z. (2006). Expression profiling of rice genes in early defense responses to blast and bacterial blight pathogens using cDNA microarray. Physiological and Molecular Plant Pathology, 68(1-3), 51-60. https://doi.org/10.1016/j.pmpp.2006.06.002

Lippok, B., Birkenbihl, R.P., Rivory, G., Brümmer, J., Schmelzer, E., Logemann, E. and Somssich, I.E. (2007). Expression of AtWRKY33 encoding a pathogen-or PAMP-responsive WRKY transcription factor is regulated by a composite DNA motif containing W box elements. Molecular Plant-Microbe Interactions, 20(4), 420-429. https://doi. org/10.1094/MPMI-20-4-0420

Moin, M., Bakshi, A., Saha, A., Dutta, M., Madhav, S.M. and Kirti, P.B. (2016). Rice ribosomal protein large subunit genes and their spatio-temporal and stress regulation. Frontiers in Plant Science, 7, 1284. https://doi.org/10.3389/ fpls.2016.01284

Meena, K.K., Sorty, A.M., Bitla, U.M., Choudhary, K., Gupta, P., Pareek, A., Singh, D.P., Prabha, R., Sahu, P.K., Gupta, V.K. and Singh, H.B. (2017). Abiotic stress responses and microbe-mediated mitigation in plants: the omics strategies. Frontiers in Plant Science, 8, p.172. https://doi.org/10.3389/ fpls.2017.00172

O’Brien, J.A. and Benková, E. (2013). Cytokinin cross-talking during biotic and abiotic stress responses. Frontiers in Plant Science, 4, 451. https://doi.org/10.3389/fpls.2013.00451

Saidi, A., \& Hajibarat, Z. (2018). In silico analysis of floral mads-box gene in Brachypodium distachyon. BIONATURE, 366-375.

Saidi, A., \& Hajibarat, Z. (2019). Characterization of cis-elements in hormonal stress-responsive genes in Oryza sativa. https://doi.org/10.35118/apjmbb.2019.027.1.10

Saidi, A., \& Hajibarat, Z. (2020). In-silico analysis of eukaryotic 
translation initiation factors (eIFs) in response to environmental stresses in rice (Oryza sativa). Biologia, 1-8. https:// doi.org/10.2478/s11756-020-00467-1

Sharma, T.R., Rai, A.K., Gupta, S.K., Vijayan, J., Devanna, B.N. and Ray, S. (2012). Rice blast management through hostplant resistance: retrospect and prospects. Agricultural Research, 1(1), 37-52. https://doi.org/10.1007/s40003-0110003-5

Song, R., Li, J., Xie, C., Jian, W., \& Yang, X. (2020). An Overview of the Molecular Genetics of Plant Resistance to the Verticillium Wilt Pathogen Verticillium dahliae. International Journal of Molecular Sciences, 21(3), 1120. https://doi. org/10.3390/ijms21031120

Sormani, R., Masclaux-Daubresse, C., Daniele-Vedele, F. and Chardon, F. (2011). Transcriptional regulation of ribosome components are determined by stress according to cellular compartments in Arabidopsis thaliana. PLoS One, 6(12), p.e28070. https://doi.org/10.1371/journal.pone.0028070

Toufighi, K., Brady, S. M., Austin, R., Ly, E., \& Provart, N. J. (2005). The Botany Array Resource: e-Northerns, expression angling, and promoter analyses. The Plant
Journal, 43(1), 153-163. https://doi.org/10.1111/j.1365313X.2005.02437.x

Ülker, B. and Somssich, I.E., 2004. WRKY transcription factors: from DNA binding towards biological function. Current Opinion in Plant Biology, 7(5), 491-498. https://doi. org/10.1016/j.pbi.2004.07.012

Yang, L., Mu, X., Liu, C., Cai, J., Shi, K., Zhu, W., and Yang, Q. (2015). Overexpression of potato miR482e enhanced plant sensitivity to Verticillium dahliae infection. Journal of Integrative Plant Biology, 57(12), 1078-1088. https://doi. org/10.1111/jipb.12348

Wang, W., Vinocur, B. and Altman, A. (2003). Plant responses to drought, salinity and extreme temperatures: towards genetic engineering for stress tolerance. Planta, 218(1), 1-14. https://doi.org/10.1007/s00425-003-1105-5

Wang, P., Du, Y., Zhao, X., Miao, Y. and Song, C.P. (2013). The MPK6-ERF6-ROSE7/GCC-box complex modulates oxidative gene transcription and the oxidative response in Arabidopsis thaliana. Plant Physiology, 112. https://doi. org/10.1104/pp.112.210724 